\title{
Persistence of rabies antibody 5 years after pre-exposure prophylaxis with human diploid cell antirabies vaccine and antibody response to a single booster dose
}

By F. M. RODRIGUES*, V. B. MANDKE*, M. ROUMIANTZEFF $†$, C. V. R. MOHAN RAO*, J. M. MEHTA $\ddagger$, K. M. PAVRI* AND C. POONAWALLA $\ddagger$

* National Institute of Virology, 20-A Dr. B. R. Ambedkar Road, Pune 411001 , India; †Institut Merieux, 58 Avenue Leclerc, Lyon, France; $\ddagger$ Serum Institute of India Research Foundation, Hadapsar, Pune 411 028, India

(Accepted 31 January 1987)

SUMMARY

In 1978, 22 staff members of the National Institute of Virology, Pune, India, were given two doses of human diploid cell antirabies vaccine (HDCV) for primary pre-exposure prophylactic immunization; the interval between the two doses being approximately 4 weeks. Eighteen of these 22 vaccinees were given a booster dose 1 year later. All 18 vaccinees developed protective levels of antibody; most of them had antibody levels exceeding $10 \mathrm{IU} / \mathrm{ml}$.

In 1984, 5 years after the booster dose, $11(79 \cdot 0 \%)$ of 14 vaccinees tested still possessed neutralizing antibody levels ranging from $0.5 \mathrm{IU} / \mathrm{ml}$ to $10 \mathrm{IU} / \mathrm{ml}$. Fourteen days after the administration of a booster dose, the antibody levels ranged from 10 to $\geqslant 100 \mathrm{IU} / \mathrm{ml}$ for all except one vaccinee $(5 \cdot 2 \mathrm{IU} / \mathrm{ml})$. These findings demonstrate that the majority of vaccinees retained detectable neutralizing antibody after pre-exposure prophylaxis for as long as 5 years and that a single booster dose thereafter evoked a good antibody response.

\section{INTRODUCTION}

Human diploid cell antirabies vaccine (HDCV) has proved to be very effective when used for post-exposure prophylaxis. There has been no reported case of rabies when the vaccine was used in the dosage schedule recommended for such prophylaxis together with rabies immune globulin (ACIP, 1984). The vaccine has also been shown to produce a good antibody response when administered in the schedule recommended in France for pre-exposure prophylaxis, i.e. primary immunization with two $1 \mathrm{ml}$ doses injected 1 month apart followed by a booster dose a year later (Aoki et al. 1975).

There are few reports on the persistence of antibody to rabies virus for long periods after pre-exposure prophylaxis with HDCV (Roumiantzeff et al. 1984). This report describes the antibody response of laboratory personnel to pre-ex-

$\S$ Present address: Enterovirus Research Centre, Parel, Bombay 400012 , India 
posure prophylaxis, the persistence of antibody for 5 years and the effect of a single booster dose after this interval.

\section{MATERIALS AND METHODS}

\section{Administration of the vaccine}

Twenty-two staff members of the National Institute of Virology (NIV), Pune, who could have been exposed to rabies virus as part of their work, were each given two doses of HDCV obtained from the Institut Merieux, Lyon, France for primary immunization, followed by a booster dose after 1 year. The $1 \mathrm{ml}$ doses were administered in accordance with the manufacturer's schedule for pre-exposure prophylaxis, except that the vaccine was inoculated by the intramuscular route in all vaccinees except one for whom the route was subcutaneous.

The interval between the first and second doses was 26-33 days for all except three vaccinees $(19,39$ and 41 days, respectively); the mean was 29 days and the median was 28 days.

The interval between the second dose and the booster dose was 11.1 months to 13.2 months; the mean was 11.6 months, the median 11.5 months.

Almost 5 years after this booster dose (range: 4 years $10 \cdot 1$ months to 4 years 11.6 months) a further booster dose was administered by the subcutaneous route.

\section{Collection of blood samples}

A prevaccination blood sample was obtained on the same day as the first dose was administered. The interval between each dose and the collection of the respective blood sample was as follows:

(i) After the first dose

26-33 days for all except three vaccinees $(19,39$ and 41 days.

(ii) After the second dose

(iii) After the 1-year booster dose respectively).

30-39 days for all except 3 vaccinees $(42,50$ and 100 days, respectively).

(iv) Between the booster dose and $35-51$ days prior to the second (5-year) booster dose

(v) After the 5-year booster dose

4 years $10 \cdot 1$ months to 4 years $11 \cdot 6$ months

Two blood samples obtained on the 7 th and the 14 th days, respectively.

The blood samples were stored refrigerated for $24 \mathrm{~h}$, after which the serum was separated from the clot. Aseptic procedures were followed at all stages. The sera were stored frozen at $-20^{\circ} \mathrm{C}$ until they were despatched to the Institut Merieux, France, as samples coded with NIV specimen numbers only, where they were tested for neutralizing $(\mathrm{N})$ antibody by the Rapid Fluorescent Focus Inhibition Test (Smith et al, 1973). 


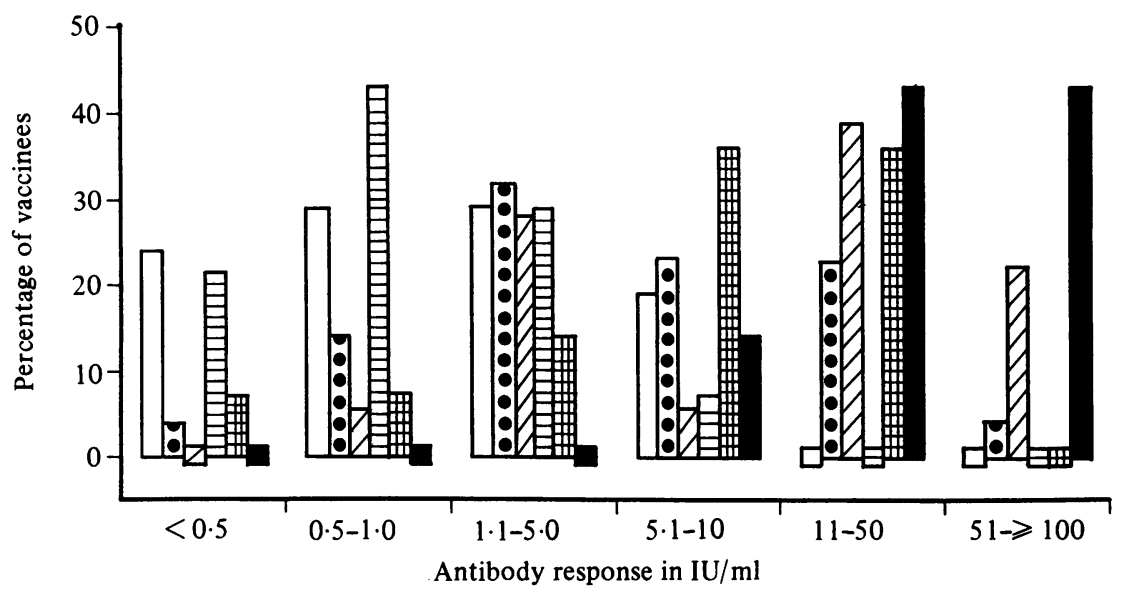

Fig. 1. Antibody response to HDCV and persistence of antibody. $\square$, After first dose ; $\square$, After second dose; $\square$, after first booster dose; $\boxminus$, persistence after 5 -year interval; 曲, 7 days after second booster dose; $\square, 14$ days after second booster dose.

\section{RESULTS}

The antibody response after each dose and the persistence of antibody over a 5year period are shown in Fig. 1.

Following the first dose, $16(76 \%)$ out of 21 vaccinees (the serum sample of one vaccinee could not be obtained after the first dose) developed neutralizing antibody levels of $0.5 \mathrm{IU} / \mathrm{ml}$ or higher. Approximately half of the vaccinees $(10$ vaccinees, $48 \%$ ) had $\mathrm{N}$ antibody levels between 1.1 and $10 \mathrm{IU} / \mathrm{ml}$.

Following the second dose of the vaccine, all except 1 of the 22 vaccinees developed $\mathrm{N}$ antibody levels of $0.5 \mathrm{IU} / \mathrm{ml}$ or higher : the exception was a vaccinee with an equivocal antibody response $(\leqslant 0.5 \mathrm{IU} / \mathrm{ml})$, who had received his second dose within the recommended time interval after the first dose (33 days). Half of the vaccinees (11 vaccinees, $50 \%$ ) had antibody levels exceeding $5 \mathrm{IU} / \mathrm{ml} ; 6$ of these 11 vaccinees had levels exceeding $10 \mathrm{IU} / \mathrm{ml}$.

The geometric mean (GM) antibody levels rose from $1.9 \mathrm{IU} / \mathrm{ml}$ after the first dose to $5.9 \mathrm{IU} / \mathrm{ml}$ after the second dose.

A booster dose could be given to 18 of the 22 vaccinees. Following the booster dose, all 18 vaccinees had protective levels of antibody and all except 1 vaccinee (level $0.5 \mathrm{IU} / \mathrm{ml}$ ) had $\mathrm{N}$ antibody levels exceeding $1.0 \mathrm{IU} / \mathrm{ml}$. The majority $(11$ vaccinees, $61 \%$ ) had antibody levels exceeding $10 \mathrm{IU} / \mathrm{ml} ; 4$ of these 11 vaccinees had levels exceeding $50 \mathrm{IU} / \mathrm{ml}$. The GM antibody level was $10 \cdot 2 \mathrm{IU} / \mathrm{ml}$.

Of these 18 vaccinees, 14 could be tested for persistence of antibody approximately 5 years after the booster dose; 11 vaccinees $(79 \%)$ still possessed $\mathrm{N}$ antibody levels ranging from 0.5 to $10 \mathrm{IU} / \mathrm{ml}$ (Fig. 1.). The GM antibody level was $1.3 \mathrm{IU} / \mathrm{ml}$.

All 14 vaccinees, except 1 , were found to have protective levels of antibody, 7 days after the administration of the second booster dose, given after the 5-year interval. The majority (10 vaccinees, $71 \%$ ) had antibody levels between $5 \cdot 1$ and $50 \mathrm{IU} / \mathrm{ml} ; 5$ of these 10 vaccinees had levels exceeding $10 \mathrm{IU} / \mathrm{ml}$. Fourteen days after the second booster dose all 14 vaccinees possessed high levels of antibody. 
Except for one vaccinee, the antibody levels ranged from $10 \mathrm{IU} / \mathrm{ml}$ to $\geqslant 100 \mathrm{IU} /$ $\mathrm{ml}$ (four vaccinees had levels of $\geqslant 100 \mathrm{IU} / \mathrm{ml}$ ). The exception was the vaccinee in whose serum $\mathrm{N}$ antibody was not detected after 7 days; the antibody level in his 14th day serum was $5 \cdot 2 \mathrm{IU} / \mathrm{ml}$.

For these 14 vaccinees the $\mathrm{GM}$ antibody levels were $1 \cdot 6,5 \cdot 6$ and $11 \cdot 0 \mathrm{IU} / \mathrm{ml}$ after the first, second and first booster doses, respectively. Five years later, the GM antibody level of $1.3 \mathrm{IU} / \mathrm{ml}$ was comparable to that after the first dose of the primary immunization schedule. On day 7 after the second booster, the GM antibody level of $8.5 \mathrm{IU} / \mathrm{ml}$ was comparable to that detected after the first (1 year) booster dose following the primary pre-exposure prophylaxis and on day 14 the GM antibody level of $36 \cdot 1 \mathrm{IU} / \mathrm{ml}$ was more than threefold higher than that after the first booster dose.

\section{DISCLSSION}

Previous studies on the persistence of immunity after pre-exposure prophylaxis and the effect of a booster dose have been carried out after intervals of 2-3 years (Nicholson, Turner \& Aoki, 1978; Plotkin, 1980). In one study, the effectiveness of a single booster dose 4 years after post-exposure prophylaxis with HDCV was demonstrated (Bahmanyar et al. 1976; Fayaz et al. 1981). The post-exposure prophylaxis in this study had consisted of one dose of rabies immune globulin and six doses of HDCV on days $0,3,7,14,30$ and 90.

The most significant findings in our study are $(a)$ in the absence of any further booster dose, 11 out of 14 vaccinees $(79 \%$ ) still had $\mathrm{N}$ antibody in levels of $0.5 \mathrm{IU} /$ $\mathrm{ml}$ or higher 5 years after the previous dose; $(b)$ of the remaining three vaccinees, two responded positively within a period of 7 days and the third within 14 days after the administration of a booster dose; $(c)$ antibody levels rose markedly during this period with GM antibody levels rising from 1.3 to $8.5 \mathrm{IU} / \mathrm{ml}$ by day 7 and to $36 \cdot 1 \mathrm{IU} / \mathrm{ml}$ by day 14 ; and $(d)$ the GM antibody level on day 14 was more than threefold higher than that after the previous booster dose 5 years earlier.

At present there are two different recommendations for pre-exposure primary immunization. Some national authorities follow the US recommendation, which consists of a schedule of three doses of vaccine administered intramuscularly on days 0,7 and 28 ; booster doses are generally recommended every 2 years, but may be given at shorter intervals to those in the higher risk groups, depending on neutralizing antibody levels. Other countries follow the pre-exposure prophylaxis recommendation proposed in 1974 in France and the UK which consists of a twodose primary immunization schedule on days 0 and 28 , followed by a booster dose 1 year later. A second booster dose is administered after $3-5$ years.

Our findings demonstrate that this simple pre-exposure schedule, i.e. two initial doses, with an interval of 1 month between the doses, followed by a booster dose 1 year later, gives adequate immunity. A further booster is effective in inducing a good neutralizing antibody response even after an interval of 5 years.

The authors are grateful for the assistance given by the Institut Merieux, Lyon, France, for carrying out the antibody estimations with special thanks being due to Dr X. Pouradier-Duteil. The vaccine used for the second booster dose in 1984 was provided free by the Serum Institute of India Research Foundation, Pune. 


\section{REFERENCES}

ACIP (1984). Recommendation of the Immunization Practices Advisory Committee on Rabies Prevention-United States, 1984. Centers for Disease Control Morbidity and Mortality Weekly Report 33, 393-408.

Aoki, F. Y., Tyrrell, D. A. J., Hill, L. E. \& Turner, G. S. (1975). Immunogenicity and acceptability of a human diploid-cell culture rabies vaccine in volunteers. Lancet i, 660662.

Bahmanyar, M., Fayaz, A., Nour-Salehi, S., Mohammadi, M. \& Koprowski, H. (1976). Successful protection of humans exposed to rabies infection : postexposure treatment with the new human diploid cell rabies vaccine and antirabies serum. Journal of the American Medical Association 236, 2751-2754.

Fayaz, A., Simani, S., Nour-Salehi, S. \& Bahmanyar, M. (1981). Booster effect of human diploid cell antirabies vaccine in previously treated persons. Journal of the American Medical Association 246, 2334-2335.

Nicholson, K. G., Turner, G. S. \& Aoki, F. Y. (1978). Immunization with a human diploid cell strain of rabies virus vaccine: two-year results. Journal of Infectious Diseases 137, 783-788.

Plotkin, S. A. (1980). Rabies vaccine prepared in human cell cultures: progress and perspectives. Reviews of Infectious Diseases 2, 433-448.

Roumiantzeff, M., AjJan, N., Branche, R., Fournier, P., Montagnon, B., Trotemann, P., \& VINCENT-FALQUET, J. C. (1984). Rabies vaccine produced in cell culture: production control and clinical results. In Applied Virology (ed. E. Kurstak, W. Al-Nakib and C. Kurstak), pp. 241-296. London: Academic Press Inc.

Smith, J. S., YAGer, P. A. \& BAER, G. M. (1973). A rapid reproducible test for determining rabies neutralizing antibody. Bulletin of the World Heath Organization 48, 535-541. 